\title{
Entrevista
}

\section{A ILUSÃO (PSICO)PEDAGÓGICA E O EMPOBRECIMENTO DAS EXPERIÊNCIAS EDUCATIVAS (ENTREVISTA COM LEANDRO DE LAJONQUIËRE)*}

\author{
Rosério Rodrigues \\ Magali Reis
}

A

psicanálise chegou ao Brasil há quase cem anos, graças à iniciativa de Durval Marcondes, Juliano Moreira, Arthur Ramos, Deodato de Moraes, entre outros. Logo depois, o questionamento acerca da possibilidade de a invenção freudiana ter efeitos no campo da educação familiar e escolar se instalou rapidamente. O próprio Arthur Ramos publica, em 1934, aquela que seria a primeira obra sobre o assunto no Brasil - Psicanálise e educação. Nesse período, tanto o interesse dos psicanalistas brasileiros pela educação quanto dos pedagogos pela psicanálise tiveram altos e baixos. No entanto, nestes últimos trinta anos, os estudos psicanalíticos na educação acabaram conquistando presença e dignidade universitárias, a tal ponto de este feito merecer destaque no cenário internacional. Nesse contexto, conduzimos uma entrevista com o professor Leandro de Lajonquière, um dos representantes desse

- Doutor em Educação pela Universidade Estadual de Campinas (Unicamp) e docente da Universidade Federal de Itajubá, Itajubá, MG, Brasil.

ש Doutora em Educação pela Universidade Estadual de Campinas (Unicamp) e docente do Programa de Pós-Graduação em Educação da Pontifícia Universidade Católica de Minas Gerais, Belo Horizonte, MG, Brasil. 
movimento intelectual, trazendo ao diálogo suas contribuições pregressas, bem como a profunda riqueza de um pensamento imaginativo e inventivo que nos conduz a refletir sobre as condições da educação no mundo de hoje.

Rodrigues: Primeiramente, gostaria de agradecer por aceitar nos conceder esta entrevista, para conversarmos sobre aquilo que você denomina como sendo os impasses da educação. Antes de iniciarmos esse assunto, você poderia nos esclarecer um pouco mais acerca do centro do impasse no campo educacional brasileiro?

Lajonquière: A pergunta me permite insistir na necessidade de precisarmos o alcance do que chamamos impasses educativos à luz dos estudos psicanalíticos na educação. Existe uma certa tendência de pensarmos as questões educativas em um sentido universal, apagando as idiossincrasias nacionais e as particularidades dos sistemas escolares. O fato de educarmos as crianças - ou seja, de nos endereçarmos a elas - acontece no interior do campo da palavra e da linguagem e, portanto, todo laço educativo, ora familiar, ora escolar, está tomado na dialética da demanda e do desejo. $\mathrm{O}$ caráter universal dos fenômenos educativos termina aqui. Já as vicissitudes e os impasses no desdobramento do laço educativo sempre se declinam ou se figuram no singular, portanto, os impasses educativos são próprios de uma época e de uma geografia determinada. Feito esse esclarecimento, creio que, hoje em dia, no Brasil, vivemos certos impasses educativos que não necessariamente acontecem em outras latitudes. O ideário pedagógico ultrapassa os limites da fronteira escolar, dos dispositivos escolares. Como simples pais, podemos ter mais ou menos consciência desse conjunto de ideias pedagógicas mais ou menos claras que "respiramos", que inspiram ou animam o laço educativo. Por outro lado, espera-se que os profissionais da educação saibam quais ideias inspiram suas ações e qualificam suas empresas. Temos, no Brasil, uma forma singular de pensar e sonhar a questão educativa, aquilo que "se passa" entre um adulto e uma criança, seja no interior da família, seja no interior das escolas. Esse "se passa" não necessariamente diz aquilo que "passa" de um para o outro, mas diz aquilo que acontece na experiência. Explico: na Argentina, costuma-se perguntar: "Che, te pasa algo?”. Ou seja, utilizo-me dessa expressão para fazer referência ao que acontece nesse encontro sempre desencontrado entre um adulto e uma criança. Então, o ideário pedagógico brasileiro se encontra atravessado, tomado, de forma ostensiva por aquilo que chamei, nos anos 1990, de ilusão (psico)pedagógica. Obviamente, essa ilusão está também presente em outras latitudes, mas aqui ela é onipresente. De que se trata? Trata-se da crença de que a 
intervenção educativa, para ser eficaz, deve ser adaptada, ajustada à criança. Essa tese está presente nos diversos artigos publicados nessa década, mas ela será qualificada de ilusão no texto Dos "erros" e em especial daquele de renunciarmos à educação (1997). Posteriormente, o sintagma ilusão (psico)pedagógica aparece no título do livro publicado no Brasil em 1999 e, posteriormente, editado em castelhano, em Buenos Aires. A tese aponta para o fato de o adulto estar tomado fantasmaticamente pela ideia de que toda educação que se preze deve ser natural, isto é, a educação deve ir ao encontro da suposta essência infantil em desenvolvimento na criança. Esse encontro deve ser perfeito, ou seja, a intervenção adulta não deve produzir resto ou suplemento algum. Em suma, a educação é sonhada no registro da conaturalidade, do complemento harmônico entre o adulto e a criança. Tudo aquilo passível de ser contranatural passa a ser traumático, contrário ao desenvolvimento natural das capacidades também naturais das crianças. Essa ilusão dá lugar a uma espécie de autopoliciamento, de autocensura que persegue tanto os pais, quanto os profissionais da educação. Assim, os adultos renunciam à educação, padecem de certo horror ao ato educativo. $\mathrm{O}$ desejo que anima essa crença é um desejo de não desejar. $\mathrm{E}$ por isso, então, o tiro educativo sai pela culatra da pedagogia! Isso significa que, em lugar de expandir as fronteiras do universo para a criança, 
a intervenção educativa faz da educação um ato de difícil acontecimento. Em outras palavras, torna mais complicada a tarefa de uma criança de encontrar para si um lugar num mundo cada vez mais reduzido a seu próprio umbigo. Mais de um século de desenvolvimentos psicanalíticos permite-nos, por um lado, suspeitar que a condição humana seja tão natural quanto o é a natureza das formigas. Por outro, alertar para o fato de se pretender que a educação não deixe a desejar - como se diz em português - é decididamente de mau augúrio. Daí que os impasses - isto é, os becos sem saída nos quais entramos na educação das crianças - sejam motivados por nós mesmos, são animados pela forma que nós temos de nos endereçarmos às crianças, de recebê-las nesse mundo. Tem a ver com os sonhos que nos governam no dia a dia com as crianças. Em particular, a ilusão (psico) pedagógica empobrece a experiência, a vida cotidiana com a criança. Torna-a insulsa, sem surpresas. Assim, só restam desvios, síndromes, problemas e deficiências que reclamam sempre mais e mais eficiência pedagógica. Isto é, que reclamam, a cada troca de governo, por mais um plano miraculoso capaz de tirar a escola de seu marasmo, como também embalam a publicidade de nosso corriqueiro mercantilismo pedagógico.

Reis: Nós gostariamos de ouvir um pouco sobre sua trajetória, sua formação intelectual, desde seus estudos na Argentina, depois sua chegada ao Brasil e o início da sua aproximação com a psicanálise $e$ as questões do campo educacional.

Lajonquière: No início da minha formação universitária, em Rosário (Argentina), estudei Direito. Meu pai era advogado e isso bem que teve certo peso! Estudei três anos, até que decidi iniciar os estudos de Psicologia na esteira de uma primeira experiência analítica que tinha iniciado algum tempo antes. $\mathrm{Na}$ época, estudava e trabalhava no departamento de recursos humanos de uma empresa construtora da cidade. Decidi também trocar de emprego. Tive a ideia de procurar emprego como professor de escola primária. Como não tinha nenhum diploma 
habilitante, a burocracia pedagógica mandou-me para a escola da cidade que ninguém queria ir. Tratava-se da última escola da cidade, situada, na época, numa das maiores favelas do lugar. Foi assim que entrei na escola, sem nenhum saber pedagógico mais ou menos sistematizado. Só contava com as minhas lembranças de infância e a minha análise pessoal. Aprendi na "marcha" ou na "marra" do encontro/desencontrado com essas crianças. Trabalhei na escola durante cinco ou seis anos, até concluir o curso de psicologia. Mas, antes de concluir o curso, inicie um outro - o de Ciências da Educação - que não deve ser confundido com o curso universitário de Pedagogia no Brasil. O chamado Curso de Ciências da Educação não habilita para trabalhar como pedagogo junto às crianças. O objetivo é formar pesquisadores para o campo da educação e formação. Já em 1988, comecei o Mestrado em Educação na Unicamp, graças ao apoio de um casal de amigos da época da militância clandestina, no final da ditadura, que tinha vindo para Campinas um pouco antes. Apresentei um projeto, que acabou dando lugar a minha tese de doutorado - De Piaget a Frend: notas para repensar o erro na aprendizagem. A (psico)pedagogia entre o conbecimento e o saber. No exame de qualificação de mestrado, a banca - presidida por Pino Sirgado e integrada por Lino de Macedo e Rubem Alves - julgou que merecia a passagem para o doutorado. Nunca antes alguém tinha passado diretamente para o doutorado na Faculdade de Educação da Unicamp. Porém, eu não queria. Pretendia defender logo o mestrado e encontrar um emprego. Foi Dermeval Saviani coordenador do CPG na época - que me convenceu do contrário. Assim, em agosto de 1992, defendi minha tese de doutoramento, não tendo mestrado algum. Meu primeiro emprego universitário foi na Faculdade de Ciências Médicas da Unicamp, num centro que ainda existe, dedicado, ao menos na época, ao campo da reabilitação das assim chamadas deficiências sensoriais. Lá fiquei por dois anos, até fazer concurso para o Departamento de Filosofia e Ciências da Educação da USP, após ter estagiado pela segunda vez na École Expérimentale Bonnevil, no inverno europeu de 1995.

Rodrigues: Como foi a construção do laboratório entre unidades, o Laboratório de Estudo e Pesquisas Psicanaliticas Educacionais sobre a Infância (Lepsi), fundado, a princípio, em conjunto com a professora Maria Cristina Machado Kupfer (IP/USP), em 1998?

Lajonquière: Sempre tive um interesse duplo. Tive interesse pela psicanálise, pela prática clínica da psicanálise e as diretrizes da cura, mas, ao mesmo tempo, um interesse singular pelo escolar. Em certo sentido - e lembrando a afirmação de Jorge Luis Borges - o sonho de Domingo Faustino Sarmiento continuava também a sonhar em mim. Portanto, esses 
dois interesses me acompanham desde aquela época, e não há nenhum que prevaleça sobre o outro. Até o dia de hoje, podemos dizer que a minha reflexão, particularmente, minhas publicações, embora se inscrevam no interior do campo freudiano, tematizam questões que dizem respeito à educação das crianças, a isso "que se passa" ou a isso que "rola" entre as gerações, como seria mais apropriado dizermos em português. Para poder entender como consigo, até hoje, conjugar esse duplo interesse, é preciso falar de Maud Mannoni, da sua obra e da minha relação transferencial com ela. Antes de vir para o Brasil, já sabia dos avanços de Mannoni que abre na França, em 1969, um dispositivo institucional experimental junto com outros psicanalistas e educadores, na esteira do espírito de revolta generalizada do maio de 1968. A École de Bonnenil foi aberta para acolher crianças psicóticas, autistas e gravemente perturbadas que, não tendo, na época, lugar algum, nem na escola comum, nem em nenhum outro dispositivo paraescolar, o único destino era o internamento em estruturas sanitárias e asilos psiquiátricos ${ }^{1}$. Quando finalizo o doutorado, decido ir à Bonneuil para realizar um estágio de um par de semanas. De retorno a Campinas, integro o Centro de Estudos e Pesquisas em Reabilitação Gabriel Porto, da Unicamp. Essa imersão numa instituição filha da ideologia reabilitadora fez que eu retomasse o estudo da singular reflexão mannoniana sobre a dita "integração dos deficientes". Rapidamente, elaboro um projeto de estágio pós-doutoral em Bonneuil, para os meses de janeiro e fevereiro de 1995, que submeto à avaliação do CNPq. Será na sequência dessa segunda estadia em Bonneuil e das conversas com Maud Mannoni que certas ideias acabarão por se ordenar em mim, graças ao acontecimento, logo mais, de um outro fato. Refiro-me ao fato de vir a conhecer Maria Cristina Kupfer que, sendo docente do Instituto de Psicologia da Universidade de São Paulo (IPUSP), tinha, um tempo antes, fundado o Lugar de Vida, na esteira de sua referência à obra de Mannoni e de sua própria passagem por Bonneuil um pouco antes de mim. Nesse contexto, presto concurso para a Faculdade de Educação da USP (FEUSP) e começo a dividir com Cristina uma série de iniciativas. Ela rapidamente me convida a participar de algumas atividades do Lugar de Vida e me apresenta a ideia de editarmos um periódico universitário que passará a se chamar Estilos da Clínica: Revista sobre a infância com problemas. Esse projeto editorial, iniciado em 1996, não só virou referência no campo dos estudos psicanalíticos na educação quanto, mais ainda, foi peça-chave do processo de instalação e constituição do próprio campo no Brasil. Hoje em dia, a revista, com seus já passados vinte anos de publicação, superou a existência daquela que foi a primeira no seu gênero, Verlag der psychoanalytische Pädagogik, que veio a desaparecer prematuramente em 1936, no contexto do avanço nazista e da diáspora judaico-psicanalítica. Nesse contexto colaborativo é que vinga a ideia de fundarmos, em 1998, o LEPSI como laboratório inter-unidades, ou 
seja, envolvendo docentes e alunos do IPUSP e da FEUSP. Na época, essa nossa iniciativa universitária também foi pioneira. Não se pode dizer que tivéssemos clareza dos objetivos. Com o passar do tempo, cada um foi tomando a dimensão do que estávamos vivendo, do que estávamos colocando em marcha. Animado pela experiência vivida em Bonneuil, a questão revestia, para mim, certa complexidade. Ao tempo que avançava na minha formação psicanalítica, valia-me da psicanálise para subverter a pedagogia especial e a ideologia segregadora. Dizer isso hoje - uma vez consolidada a ideia da educação inclusiva e reconhecido o lugar singular da reflexão psicanalítica no campo educativo - pode parecer banal, mas não o era na época. O empecilho não era tão somente a desconfiança de que a pedagogia professava em relação a Freud e a sua invenção, mas também a desconfiança de não poucos psicanalistas para quem o simples fato de pronunciarmos a palavra educação era motivo suficiente para dizer que estávamos traindo a causa freudiana, que estávamos pedagogizando a psicanálise. No entanto, o esforço de pensar além do ideário pedagógico especial e segregacionista, justificado pela ideologia psicológica desenvolvimentista, acabou inusitadamente dando lugar a uma operação intelectual singular, qual seja aquela de esclarecer graças às ferramentas conceituais psicanalíticas os princípios de uma educação que qualifiquei na esteira de minha 
experiência em Bonneuil de educaşão a seco, isto é, uma educação sem ouropéis tecno-cientificistas. Aqui, novamente, nota-se a influência na reflexão da minha língua materna castelhana, na qual o qualificativo em espanhol a secas significa "com simplicidade ou franqueza" ou "sem mais nada". Sou, há alguns bons anos, trilingue. Ministro aulas, oriento pesquisas de alunos e escrevo tanto em português quanto em francês ou em espanhol. Esse fato de passar constantemente de uma língua para outra anima singularmente minha reflexão intelectual. Quando estou travado numa língua, a reflexão continua a se desdobrar numa outra, até oferecer as chaves para retomar a questão travada na outra. Os avanços na reflexão desses primeiros anos foram apresentados em Infância e ilusão (psico)pedagógica, publicado em 1999.

Reis: Em seu livro De Piaget a Freud: a (psico)pedagogia entre o conbecimento e o saber, você afirma que o pensamento é o produto de um entrelaçamento sutil entre a inteligência e o desejo ou, sob outro ângulo, um composto entrelaçado de conhecimento e saber. Nós podemos afirmar que, quando se fala em crise da educação, seja algo parecido, que perdemos essa tradição escolar do entrelaçamento entre o conbecimento e o saber?

Lajonquière: Sim, concordo, mas, para justificar essa minha resposta, preciso fazer um rodeio e retomar a tese de doutoramento. Com ela, relancei um debate que ficara inconcluso na Argentina. Lá havia uma tradição no pensamento psicopedagógico que tem a ver com o próprio desenvolvimento da psicanálise e com o processo histórico da escolarização argentina. Retomo a reflexão de Sara Paín, que fora responsável, nos anos 1970, na Universidade de Buenos Aires (UBA), pela cátedra de Psicologia do Desenvolvimento. Ela questiona o ideário psicométrico não só a partir das linhas diretrizes da psicologia da inteligência piagetiana, senão também da metapsicologia psicanalítica esclarecida pelo ensino lacaniano. Esse trabalho ficou inconcluso na Argentina, por conta da diáspora intelectual motivada pela ditadura militar. Retomei-o para, assim, concluir - mas à minha 
maneira - que o pensamento é um singular tecido de conhecimento e saber. Por que digo à minha maneira? Embora essa afirmação seja também subscrita por outros colegas, como, por exemplo, a psicopedagoga Alicia Fernandez, não operamos necessariamente da mesma forma, nem com a psicanálise, nem com a epistemologia genética. Quem pensa? Ninguém. O individuo não é o agente do pensamento. Trata-se do campo da palavra e da linguagem. O pensamento é um tecido discursivo tomado num duplo sistema de leis disjuntas, porém inseparáveis. Há leis que o fazem operar numa direção, mas há outras que o fazem pender numa direção contrária. O pensamento resulta da impossibilidade de uma síntese. Um sistema de leis constitui o que Piaget chamou de inteligência. Mas o outro é aquele que rege a "outra cena", conforme Freud dizia, era aquela estruturada pelos pensamentos inconscientes. Dito isto, devo - ao menos rapidamente - alertar para o fato de não confundirmos, na minha formulação, nem a inteligência com consciência - o que daria a dicotomia psicológica consciência/inconsciência -, tampouco o inconsciente freudiano com a dita afetividade, o que resultaria numa outra dicotomia psicológica bem conhecida, aquela entre a inteligência e a afetividade. Meu trabalho de tese, justamente, constrói-se na tentativa de dissolver esses dois obstáculos epistemológicos, no sentido de Bachelard. Assim, o pensamento está duplamente articulado entre conhecimento e saber, onde um não é o que ao outro faltaria para fazer um. Não há, então, união, tampouco interseção entre as duas ordens. Uma implica a existência da outra como seu avesso necessário, formando uma dupla disjunta, em que impera a indeterminação. No limite, ambas têm uma mesma origem indistinta, sempre recalcada lá, no umbigo da linguagem, assim como Freud falava do umbigo dos sonhos. Então, lá, onde a linguagem torna-se rarefeita, toda palavra avizinha e disjunta conhecimento e saber. Dito isso, retomo, então, o questionamento sobre como a tradição escolar desconhecer o entrelaçamento entre conhecimento e saber. É claro que isso se perfila singularmente conforme as épocas e as latitudes. Mas é possível dizer que impera, hoje em dia, certa fantasia de que as crianças são simplesmente uma máquina inteligente, uma máquina processadora de informações. Portanto, se a criança processa informação, então, o papel do professor seria apenas aquele de transmiti-las, ficando a transmissão reduzida a uma questão comunicacional, isto é, a "passar" ou "dar" informações ou conteúdos mais ou menos científicos. É interessante notar que os jovens professores de escola, logo quando você os encontra, dizem: "mas a criança que tenho na sala de aula não é aquela da qual falavam na faculdade". Pois é, a criança da sala de aula está viva, já a dos livros, morta. Por quê? Porque, as crianças 
da faculdade só existem nos livros. Já a criança de carne e osso, essa que está em casa, nas escolas, nas ruas, nos parques... está viva. O que isso significa? Significa que ela espera de nós alguma coisa mais que uma simples informação, espera de nós uma palavra. A criança espera primeiro ser escutada e, em retorno dessa escuta, justamente uma palavra que reconheça à criança a sua dignidade, isto é, a dignidade do desejo que a anima. Por sinal, fui, nestes dias, em São Paulo, ao cinema ver um filme francês cujo título original traduzido deveria ter sido Os grandes espiritos [Les grands esprits (2017), filme de Olivier Ayache-Vidal, com atuação de Denis Podalydès, membro da Comédie Française]. No entanto, por conta dessas coisas da divulgação comercial, foi traduzido como $O$ melhor professor da minha vida. Creio que a escolha do título no Brasil diz um pouco de nosso imaginário sociopedagógico. Primeiro, não sei se o professor do filme é o melhor professor da vida dessa garotada e, em particular, do garoto com o qual o filme termina. $\mathrm{Na}$ última cena, vê-se o professor e um garoto sentados num banco, ambos confrontados com um desengano amoroso. Segundo, o título francês Os grandes espiritos cai como uma luva, conforme dizemos em português. Temos um professor de literatura francesa num dos mais prestigiados colégios públicos ${ }^{3}$ da França - o Lycée Henri IV (fundado em 1796 sobre um sítio monacal que remonta ao século XVII) - que, devido a um mal-entendido, numa conversa com uma mulher pela qual se sente atraído, vê-se transferido provisoriamente e em caráter experimental para um colégio da periferia pobre de Paris ${ }^{4}$. Numa cena, vemos o professor lançar literalmente exemplares de $O s$ miseráveis (Les misérables, de Victor Hugo) aos alunos, até esse momento resistentes ao seu ensino, à sua presença. O escritor Victor Hugo foi inumado no Panthéon: não há dúvidas de que se trata de um grande espírito! O filme diz da imperiosa necessidade de entrarmos em contato com os grandes espíritos, com aqueles que não só fazem a nação, mas que revelam simplesmente a fragilidade e a sutileza da nossa condição humana. Esses espíritos habitam os livros, esses que precisamente chamamos de clássicos, as artes, a literatura, o cinema, a música. Os adultos de carne e osso, os professores, os pais e as mães que somos, somos simplesmente passadores, embaixadores desses grandes espíritos para as crianças chegadas ao mundo depois de nós. Nesse sentido, quando a educação se reduz, em particular, à educação escolar, ao desenvolvimento de competências para se arrumar um emprego num futuro mais ou menos longínquo - é só ver as mensagens publicitárias veiculadas no metrô de São Paulo - corre-se detrás de uma miragem no deserto, pois os empregos de hoje nunca foram necessariamente os empregos de amanhã - diga-se de passagem, menos ainda nessa fase da humanidade. Entretanto, os grandes espíritos estão sempre aí, nunca nos abandonam! Assim, quando nos endereçamos às crianças como embaixadores de grandes espíritos, ficamos pequenos em relação a eles, mas, paradoxalmente, 
nossa palavra ganha estofo, ganha um peso específico, tal que a criança nos escuta, além de qualquer reclame contingencial mais ou menos barulhento. Essa palavra ressoa e, assim, faz que a criança entre em ressonância com esses grandes espíritos que, habitando nosso único mundo, fazem com que este seja sempre velho para toda e qualquer criança que bate às suas portas.

Rodrigues: Parece que hoje existe uma ideia predominante de que educação é somente aquela científica e pautada no discurso hegemônico da naturalização e adaptação. A partir do pressuposto teórico da psicanálise na educação, como você vem lidando com essa demanda para não naturalizar o sujeito?

Lajonquière: Segundo Freud, a grande maioria das pessoas é formada por neuróticos mais ou menos inteligentes e/ou simpáticos. Isso significa que suportamos como podemos essa divisão subjetiva que é o desejo. É sobre o desejo que queremos saber e, ao mesmo tempo, não queremos saber, que não podemos saber, que não há saber sobre o desejo. Portanto, o neurótico faz qualquer negócio para acreditar que haveria saber ao alcance da mão. Por isso, os pais, as mães, os professores, todos nós, caso não tomemos certo cuidado, caímos facilmente no conto do vigário, como se diz em português. Qual seria esse conto? Pois é, toda receita que se prescreve às pessoas, como fazer para dar uma boa aula, para tratar ou educar a criança sem supostamente vir a "traumatizá-la" etc. Por outro lado, a psicanálise não prescreve o que deve ser feito em nenhuma esfera da vida. No que tange à educação, sustento há anos que "a psicanálise na educação" alerta para aquilo que não deve ser feito sob pena de fazer da educação de uma criança um fato de difícil acontecimento. Em outras palavras, se escorregamos na tentação de fazer aquilo que não deve ser feito, embaralhamos as condições de possibilidade de uma educação vingar, ou seja, essas que são estruturais ou necessárias ao desdobramento de todo laço social educativo. Aquilo que não deve ser feito é justamente tomar a criança como álibi. Tomar a criança para ilustrar a suposta verdade de uma teoria qualquer. Em outras palavras, educar a criança com vistas a mostrar que temos razão. Perante isso, as coisas se complicam para a criança, no sentido de vir a conquistar um lugar de enunciação em nome próprio no mundo. Impõe-se a ela um trabalho redobrado para situar no horizonte educativo o desejo que anima o adulto. Situar o desejo no adulto é como situar o norte com uma bússola. Quando a criança fracassa de fato nessa empresa, fica atravessada pela demanda adulta, repetindo os ditos adultos, ou fica prostrada numa inibição mais ou menos radical. Maud Mannoni alertava para o risco de a criança não abrir mão de seu sintoma quando este lhe possibilita precisamente capturar ou formatar o desejo no adulto. Aqui, a criança não abre mão de seu padecimento, de seu lugar vitimário. Sobre o particular, cansei de escutar, mesmo na universidade,

440 Estilos clin., São Paulo, v. 23, n. 2, maio/ago. 2018, 430-450. 
jovens que chegam a se apresentar como portadores de alguma "menos-valia". Por exemplo, antes de realizar uma prova escrita, um aluno brasileiro ${ }^{5}$ me diz: "Professor, fique sabendo que eu trabalho", ao qual respondi "Que bom! Você tem sorte?". É nesse tipo de circunstância que a psicanálise alguma coisa nos ensina. De nada adianta tentar convencer o outro, impõe-se então uma intervenção que, embora possa ser julgada por terceiros como uma grosseria, venha a "chacoalhar" o sujeito afim de que descole dessa posição. Creio que cabe a todo docente ficar atento a esse tipo de situação. Em última instância, o dito papel do professor não é simplesmente comunicar informações, transmitir ou mesmo mediar a construção dos conhecimentos, como costuma-se dizer. Todo aluno espera, sem saber que o professor possa, em algum momento, proferir uma palavra capaz ressoar além do ensino. Uma palavra suscetível de relançar o trabalho de conquista de um lugar de enunciação em nome próprio, de um lugar para si e não simplesmente para o gozo dos outros, do Outro. Para que esse processo possa eventualmente ser relançado quando inibido, o docente deve ficar atento ao caráter assimétrico de sua posição com relação ao aluno. Cabe ao docente a responsabilidade da direção do processo educativo. Este responde a certas coordenadas estruturais, a certos princípios de funcionamento que dão certo "poder", mas um suposto poder. O docente deve, justamente, renunciar o poder real sobre o aluno. Ele deve aceitar ser o depositário de um poder suposto. Eis aí a tal reclamada autoridade! O paradoxo que muitos não suportam é precisamente este: para a palavra docente se revestir de autoridade, o professor deve renunciar sua pretensão bem humana de deter um poder real sobre a pessoa do aluno. Tão somente a autoridade da palavra docente é capaz de relançar a conquista de autonomia moral ou liberdade do aluno, do discípulo. Nosso trabalho não consiste em agradá-lo, nós estamos aí para dirigir um processo, um processo que supõe, no final, a liberdade. O que significa? A liberdade não consiste em fazer o que nos dá na telha. Essa é uma ideia rasa e costumeira. Só há liberdade junto aos outros. O homem realiza sua humanidade sempre inconclusa no laço social. Entrar na roda do laço social não é nada natural ou automático, como se pensa. O homem não é movido por um instinto gregário. À luz da psicanálise, o fato de participar do desdobramento do laço social resulta ser um efeito educativo. Esse feito é possível pela entrada em ressonância de duas iniciativas: por um lado, a do adulto de se endereçar à criança, de não recuar no laço educativo e, por outro, aquela da criança ou o jovem de se fazer de um lugar para si, a partir daquilo que o adulto coloca em circulação. Alias, não só o homem não é um animal gregário, mas ele tampouco é um animal racional. A sua singular natureza - por sinal, tão singular que acaba sendo nada natural - o impossibilita de ser um animal. No entanto, ele bem pode ser bruto. Mas não confundamos brutalidade humana com o ser natural dos animais. 
Reis: Houve um momento, na sua carreira, que se constituiu uma alteração de uma chave conceitual que era psicanálise E educaşão para psicanálise NA educação? Quais foram as motivações para essa mudança de nomenclatura e quais foram as suas implicações?

Lajonquière: Primeiramente, essa mudança diz respeito a um deslocamento na minha própria referência à psicanálise. Apresento-me, hoje em dia, como um psicanalista que trabalha, pensa, analisa, bem como ensina algo da psicanálise a quem interessar possa no interior do campo pedagógico. Obviamente, essa mudança se processou aos poucos, até que, subitamente, a ideia do que estava a fazer se me impôs. Nesse sentido, foi fundamental o contato progressivo que fui estabelecendo com colegas franceses e que acabou dando lugar à situação atual, ao fato de desenvolver atividades de docência e orientação em ambos os lados do Atlântico. A referência à psicanálise da quase totalidade dos colegas franceses que trabalham atualmente no campo pedagógico não é mesma que a nossa aqui no Brasil, bem como não é a que eu mantenho. Foi no confronto com essa diferença que me veio a ideia de nomear o que estava a fazer, nessa época, de uma outra forma. Explico: tinha acabado de entrar na FEUSP, e Elisabete Morkrejs, que iria logo mais se aposentar, convida Jean-Claude Filloux - já na época professor aposentado pela Université Paris Nanterre - para realizar uma série de seminários de psicanálise e educação durante uma semana. Um 
par de anos depois, o convidamos, com Cristina Kupfer, para palestrar naquele que passaria a ser o primeiro de uma longa série de colóquios internacionais do LEPSI. Com Jean-Claude, tecemos um laço de amizade. Foi ele que me apresentou diversos colegas em Paris, com os quais trabalho hoje. De certa maneira, foi uma peça importante de meu projeto de desembarcar na França ${ }^{6}$. Graças a ele, descubro o que vem sendo desenvolvido na universidade, em nome da psicanálise, no interior dessa área disciplinar que fora criada no fim dos anos 1960, início dos 1970, e que os franceses chamam "as ciências da educação". Por sinal, o Departamento de Ciências da Educação de Nanterre foi criado pelo próprio Jean-Claude, logo no início da fundação dessa universidade, na esteira do desmembramento da velha Université de Paris. O primeiro departamento no país tinha sido criado, um tempo antes, por Gaston Mialaret, na Université de Caen Normandie, na qual também desenvolvi atividades de ensino. Naqueles anos, a psicanálise tem uma presença importante no meio intelectual. Por outro lado, os desenvolvimentos da pedagogia institucional e da psicologia de grupos tinham alcançado certa maturidade. Nesse contexto, então, é que no interior desse novo campo das ciências da educação começa a se perfilar aquilo que hoje é conhecido como "Abordagem clínica de orientação psicanalítica nas ciências da educação" que, até certo ponto, resulta desse crisol de ideias. No entanto, paralelamente a essa linha de reflexão instalada no campo universitário das ciências da educação, tem início também nesses mesmos anos a expêriencia da escola de Bonneuil, que dará lugar a outra reflexão sobre a educação, a partir de outra forma de fazer comparecer a psicanálise e seus avanços no campo educativo. Assim, temos duas tradições de trabalho. Por um lado, desenvolvimentos psicanalíticos que prolongam aqueles de matriz anglo-saxônica - em particular Wilfred Bion, Esther Bick - e se apresentam como uma corrente de pensamento singular no contexto das ciências da educação. Mas, por outro, o trabalho de psicanalistas, como Françoise Dolto e Maud Mannoni, que reivindicam a possibilidade de operar com a psicanálise no campo educativo, até então reservado ao discurso monolítico da pedagogia e prestes a ser reivindicado pelas ciências da educação. Essa operação visa precisamente subverter o discurso pedagógico hegemônico apostando que o "esclarecimento psicanalítico" - este era o termo usado por Mannoni - venha a liberar as amarras da educação ou - como propus há quase vinte anos - que ele desse lugar a uma educação a seco. Nesse contexto, pode-se, então, entender porque deixo de lado o sintagma "psicanálise e educação" e passo a nomear o trabalho que venho desenvolvendo em Figuras do infantil (2009) como sendo a mesmíssima "psicanálise na educação". Por sinal, num texto recente, dediquei-me a apresentar algumas das diferenças entre os desenvolvimentos franceses e brasileiros publicado na revista de educação da Universidade Federal do Paraná. 
Rodrigues: Você afirmou, anteriormente, que existe a questão de uma criança viva, de carne e osso, e uma criança morta, que está nos manuais, nos livros. Nesses dois lugares que você está transitando - Brasil e Franca - e inserido agora na Universidade Paris VIII, como é que você identifica onde as crianças estão vivas e onde estão mortas, e em que lugar há uma riqueza e uma possibilidade para pensar a psicanálise na educação, on existe uma equivalência entre esses dois campos?

Lajonquière: A primeira observação que devo fazer é que eu não tenho dois países, mas, de fato, três. Embora a agenda de trabalho seja um problema, continuo trabalhando na Argentina. A grande parte do meu trabalho de orientação de mestrado e doutorado acontece no Brasil e na França, mas também tenho alunos na Argentina. Nestes últimos anos, concentrei minha colaboração com a Faculdade Latino-Americana de Ciências Sociais (FLACSO) - sede em Buenos Aires - e com a Faculdade de Psicologia da Universidad Nacional de Mar del Plata. Sou membro fundador, com colegas que foram meus alunos, da rede de investigação INFEIES. De fato, tiro proveito dessa passagem permanente de fronteiras: três países, três tradições universitárias singulares, três línguas, três formas de vivermos com as crianças. Esse atravessamento de fronteiras é parte integrante de minha reflexão. $\mathrm{O}$ fato de experimentar, em carne própria, a impossibilidade de haver uma tradução entre esses três mundos possibilitou-me pensar que, além das singularidades, aquilo que parasita toda educação - toda acolhida de uma criança no mundo - é como chegarmos a estar certos de algo e termos a coragem de falar disso a uma criança. Justamente, a impossibilidade de formatarmos essa questão, essa ferida narcisista, acaba por desbaratar toda empresa pedagógica, pouco importa qual seja o país. Cada país tem seu éthos pedagógico, habitado por fantasmas mais ou menos singulares que não só assombram os pais de família, mas também os sistemas escolares nacionais. Os sistemas educativos - ou a falta deles - têm a ver com idiossincrasias nacionais tomadas no tempo histórico. Isso faz que a experiência do tempo

444 Estilos clin., São Paulo, v. 23, n. 2, maio/ago. 2018, 430-450. 
da infância esteja intimamente relacionada com o modus vivendi num país determinado. Por exemplo, minha filha, hoje com 11 anos, mora num bairro não tão central de Paris, mas por onde costumam passar alguns quantos turistas. Onde não há turistas hoje? A minha filha começou a ir sozinha para a escola, que ficava a três quarteirões de casa, quando fez 8 anos $^{7}$. Naquele tempo, não ia sozinha ao parque que tínhamos perto. Porém, logo mais, passamos a acompanhá-lha, até encontrar as suas amiguinhas. Depois, passávamos a buscá-la pelo parque Georges-Brassens um pouco mais tarde. Hoje em dia, ela - como qualquer outra criança desloca-se sozinha no bairro, vai à piscina pública, à biblioteca, ao conservatório municipal, à aula de karatê e - claro está - à casa das amigas. Costumo dizer que, de certa forma, as crianças de Paris - cidade com dois milhões e meio de habitantes e um milhão de turistas todos os dias - tem ainda algo da infância que eu tive, nos anos 1960, em Rosário, na Argentina. Vida cotidiana essa como aquela da Mafalda, da história em quadrinhos de Quino, e seus amigos. Infelizmente, essa infância desapareceu em Rosário. Meus sobrinhos, quando pequenos, não brincaram sozinhos nos parques, assim, seus pais - como os paulistanos - ficaram levando de um lado para o outro. Alguém vai me dizer que o problema é de manutenção dos parques! Não há dúvidas de que os parques e praças não têm manutenção e, quando chegam a ter alguma, sempre alguém já se encarregou de destruir um pouco antes. Mas a questão fundamental é: como sonhamos as crianças? Em que lugar as sonhamos? Se as sonhamos como consumidoras de celulares ou processadoras de informação, se as sonhamos "prontas" ou "acabadas", ou seja, que nada teriam a viver de diferente ou a experimentar junto a outras crianças, então, os parques, as praças, as ruas, os espaços públicos passam a ser supérfluos nas cidades. Ao contrário, se pensarmos que as crianças precisam ficar um tempo fora do radar dos pais, nos parques ou nas praças, para depois ir merendar na casa de alguém, aí o velho urbanismo passará a render votos nas eleições ${ }^{8}$.

Reis: Leandro, você fala de sua inserção em três países, e isso é notório em sua produção acadêmica, como você avalia essa trajetória intelectual nesses três países?

Lajonquière: Para mim, é uma grande oportunidade. Ela se impôs a mim, pois até certo ponto não a busquei de forma deliberada, programada. Mas tiro, de fato, proveito dela, das formas mais inusitadas. Por exemplo, certo dia, num ano que minha família tinha ficado a morar em Paris, quando eu já tinha retornado para reassumir minhas as tarefas na USP, após o término de um pós-doutorado, fui buscar minha filha na saída da pré-escola (ela estava com quatro anos). 
Eu havia chegado a Paris nesse dia para passarmos um par de semanas juntos e fui lhe fazer uma surpresa. Então, após termos nos encontrado e abraçado, começamos a caminhar para irmos à casa e eu lhe pergunto, em português, como tinha sido esse dia na escola. Ela me responde prontamente em francês: "j'ai beaucoup travaillé, papa" [papai, trabalhei bastante]. Bom, imediatamente que escuto a sua resposta - por sinal, resposta correta em todos os sentidos, na língua francesa, para minha pergunta em português - ocorreu-me pensar que, de fato, toda educação entranha a realização de um esforço, de um trabalho psíquico a contrapelo do que pensamos corriqueiramente. Em francês, não tem sentido uma criança utilizar o verbo estudar para dizer que ela passou o dia na escola. A língua francesa impõe pensar aquilo que as crianças fazem nas escolas em termos de um trabalho realizado. Cada língua, ou o saber de cada língua, bem pode dar a escutar o que uma outra recalca e vice-versa. Para mim, esse dia, ficou claro que toda criança deve responder com trabalho à demanda educativa adulta. Assim, chegamos à minha afirmação sobre o que implica educar: o transmitir marcas de pertencimento, de filiação, que possibilite à criança conquistar para si um lugar de enunciação em nome próprio no campo da palavra e da linguagem ou, se preferirem, um lugar de palavra numa história. Conquistar significa responder à realização de um trabalho psíquico. Conquistar para si um lugar no sonho dos outros. A história já está em curso quando a criança chega ao mundo. Então, trata-se de entrar no mundo que está andando. Toda criança depara, quando chega à vida, com o desafio de ter de entrar num mundo que está andando. Costumo dizer que é como pegar um bonde andando. De fato, sou da época em que se podia subir nos ônibus quando estes andavam devagar. Em suma, tiro de fato benefício da passagem de fronteiras, da minha experiência de vida em cada um desses três países.

Rodrigues: Como você interpreta a questão do trabalho na escola? Parece que, na educação brasileira, comprende-se que o trabalho entra na escola somente quando é técnico ou profissionalizante. Isso não é o mesmo trabalho do exercício escolar, como sua filha falou: "Papai, trabalhei na escola", ou é outra entrada do trabalho no campo escolar?

Lajonquière: $\mathrm{O}$ trabalho é visto de forma reducionista. $\mathrm{O}$ trabalho do espírito no sentido da tradição humanista não é considerado. Cada um de nós, pelo simples fato de termos chegado ao mundo, temos o direito de nos entregarmos a esse trabalho do espírito e de tirarmos os benefícios. A escolarização massiva data do final do século XIX. Nos países nos quais o Estado visava se modernizar, bem como a vida na polis, democratizar-se como, por exemplo, a Argentina, abre-se o debate sobre a fundação de um sistema educacional para um país que pretende ser novo por oposição a um velho, caracterizado pela

446 Estilos clin., São Paulo, v. 23, n. 2, maio/ago. 2018, 430-450. 
opressão, pela miséria etc. E também o caso da França, no qual a emergência da ideia da Ecole de la République, no início dos anos 1880, estava relacionado com o anseio de se alicerçar uma polis republicana e democrática e, assim, sepultar à deriva que fora a eleição presidencial de um golpista convertido em emperador - Luís Napoleão ou Napoleão III. A luta pela escolarização massiva que entranha a ideia de que uma nação é muito mais que a somatória das idiossincrasias familiares. $\mathrm{Na}$ Argentina, Domingo Faustino Sarmiento será uma peça-chave. Professor de escola primária, jornalista, ensaísta, militar e político, vira presidente da República. De fato, tratou-se de um personagem excessivo. Tudo em Sarmiento foi um excesso! Pois é, só ele para sustentar com "a pena, a espada e a palavra" - conforme reza o hino a sua memória - o sonho de uma "escola para todos". $\mathrm{Na}$ virada do século XIX para o XX, a Argentina tinha conseguido instalar um sistema educativo capaz de alfabetizar quase a totalidade da população infantil. Ela chegou a apresentar índices de alfabetização superiores inclusive aos franceses e aos ingleses. O país viveu, naquela época, uma grande explosão demográfica. Em 1885, a população urbana era em torno de um milhão e meio de habitantes. Quinze anos depois, pula para os quatro milhões e meio. Três milhões de habitantes chegam de diferentes cantos do planeta, falando línguas díspares. As crianças desses recém-chegados vão se beneficiar de uma escola tomada do sonho iluminista do acesso universal ao saber. Por que falo em termos de um sonho? Porque o homem se faz humano pelos sonhos. A vida de todos os dias sempre lhe falta um pouco para ser como nos sonhos. Porém sem sonhos não há vida que possa ser vivida: a vida cotidiana vira um pesadelo. No que tange aos sistemas escolares, quando não são habitados por um sonho, eles são tomados pelo frenesi das reformas. Não é, por acaso, o que acontece no Brasil? No Brasil entra reforma, sai reforma em nome de uma sempre suposta eficiência. Vira e mexe, pretende-se reduzir o ensino da história. Mas isso é descabido! É como dizer para um italiano 
que se vão reduzir as horas de latim, é como dizer para um francês que o ensino da história da França será reduzido a um dos períodos da nação. Pensar que o ensino de história pode ser reduzido para deixar lugar para um ensino mais ou menos utilitário, mais ou menos instrumental de competências é um absurdo não só histórico quanto psíquico! Irmos à escola sem chances de darmos de cara com os grandes espíritos carece de sentido algum, mais ainda, vira um pesadelo escolar do qual a criança tentara escapar, ora se rebelando ruidosamente, ora caindo na anorexia de saber. $\mathrm{Na}$ escola, a criança deve - em certo sentido e como dizemos em português - ter oportunidade de dizer a que veio à vida. Ou seja, ela deve poder dar provas a si mesma da sua dignidade humana, de seu investimento nesse trabalho de conquista de um lugar na história em curso. Para se aceder ao saber, os saberes, ou ao conhecimento - como se diz em português - requer-se de algo mais que o ensino dos conhecimentos. O saber por si só não "cola", isto é, não adianta colocar um professor que vai repetir como se fosse um papagaio. Por sinal, é por isso que tenho desconfiança da educação a distância. O saber em si não cola, o que "dá liga" é o desejo que não é outro que seu avesso. Os adultos, os professores, são - como dizia embaixadores desse outro mundo habitado por grandes espíritos. É em nome deles que ensinamos às crianças. Mais ainda, é em nome da dívida que temos com eles que nos endereçamos às crianças. $\mathrm{Na}$ educação trata-se, assim, de darmos testemunho do desejo que nos habita, de nossa sujeição à história. Então, você me perguntou: por que três línguas? Pois - como eu disse -, porque para mim, talvez, não possa ser de outro jeito.

Reis: Você gostaria de falar um pouco mais sobre o seu último livro?

Lajonquière: Por sinal, ele já é velho. $\mathrm{O}$ [livro] Figuras do infantil (Lajonquière, 2009) foi escrito em português, em Paris, na época do meu pós-doutorado, mas, tendo no retrovisor a minha infância, o tempo da minha infância passada na Argentina. Esse livro foi posteriormente traduzido por profissionais para ser publicado na Argentina e na França. Ele está esgotado. Estou pensando em escrever a continuidade. Mas, antes, devo arranjar um pouco de tempo. Não sei ainda em qual língua vou continuá-lo.

Rodrigues: Leandro, nós agradecemos esse momento e consideramos que essa conversa vai durar mais alguns bons anos, pelo tempo que você permanece por aqui entre nós, no Brasil.

Lajonquière: Muito obrigado! Obrigado, Magali, Rogério. Bom, é um prazer, como sempre, conversar com meus colegas brasileiros e, claro, sim, espero revê-los. 


\section{REFERÊNCIAS}

LAJONQUIÈRE, L. (1992). De Piaget a Freud: a (psico)pedagogia entre o conhecimento e o saber. Petrópolis, RJ: Vozes.

LAJONQUIÈRE, L. (1994). Deficiências sensoriais e subjetividade: notas críticas à ideologia reabilitadora. Educação e Sociedade, 15(48), 304-325.

LAJONQUIÈRE, L. (1997). Dos "Erros" e em especial daquele de renunciar à educação. Estilos da Clínica, 2(2), 2743.

LajonquiÈre, L. (1999). Infância e a ilusão (psico)pedagógica: escritos de psicanálise e educaşão. Petrópolis, RJ: Vozes.

LAJONQUIÈRE, L. (2009). Figuras do infantil: a psicanálise na vida cotidiana com as crianças. Petrópolis, RJ: Vozes.

LAJONQUIÈRE, L. (2013). Maud Mannoni: L'institution éclatée. In D. DRIEU (Org.), 46 commentaires de textes en clinique institutionnelle (pp. 45-54). Paris, Frane: Dunod.

LAJONQUIÈRE, L. (2017). Elucidação comparativa dos estudos em psicanálise e educação na França e no Brasil. Educação em Revista, (64), 19-33.

\section{NOTAS}

1. Leiam-se os capítulos dedicados à Bonneuil no livro Infância e ilusäo (psico)pedagógica, bem como o texto "Maud Mannoni: L'institution éclatée" (Lajonquière, 1999, 2013).

2. Leia-se o texto "Deficiências sensoriais e subjetividade: notas críticas à ideologia reabilitadora" (Lajonquière, 1994).

3. Porém o cartaz publicitário no cinema anunciava que o personagem estava indo trabalhar num colégio público dando a entender que ele trabalhava num estabelecimento particular. Trata-se de um lapso de linguagem revelador.

4. E digno de nota a qualidade do prédio do colégio de periferia. O que não faz desse colégio nenhuma exceção.

5. Na França um argumento como esse é impossível, pois todo jovem, mesmo quando "não precisa", realiza pequenos trabalhos para pagar seus gastos pessoais. Entretanto, um aluno universitário bem pode esgrimir uma "deficiência natural" como, por exemplo, a dislexia para justificar suas faltas de ortografia. 
6. O amigo faleceu em 3 de março de 2017.

7. Note-se que, quando do primeiro dos últimos atentados terroristas em Paris, o primeiro reflexo foi dos pais - meu, inclusive - de acompanharem as crianças à escola. Porém, um par de dias bastou para retomarmos os hábitos costumeiros.

8. Note-se que a vida nos grandes condomínios comercializados sob o mote de se reencontrar a simplicidade da vida de outrora reiteram o modo de vida segregativo. Cada um constrói um outro muro para cercar a sua casa e criança alguma brinca na rua.

rogerio@unifei.edu.br Av. BPS, 1303. Caixa Postal 50. 37500903 - Itajubá - MG - Brasil.

magali_reis@pucminas.br

Avenida Itaú, 505, gabinete 310 30535-910 - Belo Horizonte - MG - Brasil.

450 Estilos clin., São Paulo, v. 23, n. 2, maio/ago. 2018, 430-450. 